\title{
Mothering in an Increasingly Uncertain Economic Marketplace: Revisiting the Call for Broader Conceptualizations of Parenthood and Paid Work
}

\author{
Elizabeth R. Paré \\ Oakland University \\ * Please address correspondence to Elizabeth R. Paré, Ph.D., Oakland University, \\ Monitoring \& Communications Manager, School of Health Sciences, and \\ Lecturer, Department of Sociology, Anthropology, Social Work \& Criminal \\ Justice, 2057 Human Health Building, Rochester MI 48309-4452. Email: \\ pare@oakland.edu.
}

\begin{abstract}
Just over ten years has passed since my coauthor, Heather Dillaway, and I added to the discourse on paid work and motherhood. At that time the cultural discourse on "stay-at-home" and "working" mothers presented a dichotomy that largely ignored the complex, diverse experiences of women and work. This follow-up essay explores recent changes within the United States and the impact these changes have had on the conceptualizations of parenting and work. This updated piece describes how decreased economic security among individuals within a global economy has helped to alter the discourse on mothers. I argue that the discourse is now less about the dichotomous divide between working and stay-athome mothers, and more about mothers securing their economic citizenship through their children via "intensive" mothering.
\end{abstract}

Key Words: motherhood, fatherhood, paid work, stay-at-home mother, working mother, conceptualization, critique

Over ten years ago, my co-author and I wrote our article, "Staying at Home" versus "Working": A Call for Broader Conceptualizations of Parenthood and Paid Work," for the Michigan Family Review. Like other feminist scholars before us (e.g., Garey, 1999; Hondagneu-Sotelo, 2001; Uttal, 2004), we argued that "the dichotomous construction of mother versus worker oversimplifies the complexities of motherhood” (Paré \& Dillaway, 2005). Further, we argued that current cultural discourse on working versus stay-at-home mothers oversimplified and ignored the level of interaction that mothers, regardless their labor force status, have with their children and that it supported an unattainable expectation of being a "good" and "intensive" mother. In reviewing the landscape in the early 2000s we also recognized that a false dichotomy between working and stay-at- 
home mothers ignored a changing economic reality that required maternal workforce participation, discounted the roles fathers have in raising children, and was not inclusive of women's diverse mothering experiences. In this updated essay, I argue that current discussions on motherhood and work, while altered due to recent structural transformations in the economy, have strengthened the “intensive mothering” expectations. Further, cultural discourse still oversimplifies the reality of mothers' and families' lives, and continues to mask the variation of women or men's roles in families.

\section{Changes in the Economy}

In the original essay (Paré \& Dillaway, 2005), we held that structural transformations of the economy were an essential force to understand, if we are to comprehend the social shifts within family and paid work activities (see also Baca Zinn \& Eitzen, 2005; Dill et al., 1998; Mann et al., 1997; Newman, 1994; Rubin, 1994; Smith, 1993). In the years since we discussed the interconnection of these topics, individuals living in the U.S. have experienced a collapse of the housing market (in 2006) and a subsequent Great Recession (2007-2009), with the latter described as the most impactful economic event that families have experienced since the Great Depression (Rose \& Winship, 2009; Ellen, \& Dastrup, 2012). These events resulted in a credit crunch, record home foreclosures, increased unemployment rates, and a decline of labor force participation particularly among men (Greenstone \& Looney, 2010; Hyra, Squires, Renner, \& Kirk 2013; Kirk \& Hyra 2012; Wachter \& Smith 2011; Cline \& Nolan, 2014). As these events unfolded the decline of the middle class accelerated, depressing median household incomes and economic security (DeNavas-Walt, Proctor, \& Smith, 2012). Concurrently xenophobia, isolationism, nationalism, and economic populism began to resurge in the U.S., because of increased middle-class familial anxiety (Bonikowski, \& DiMaggio, 2016; Goldstein, \& Peters, 2014; Inglehart, \& Norris, 2016). Today, the economic forecast is still an uncertain one for many U.S. families with less families qualifying as "middle class. Studies suggest that the decline of the middle class continues to intensify (Kochhar, Fry \& Rohal, 2015).

\section{Motherhood, Work and the Global Market}

A vigorous debate has been underway for decades, if not centuries, on whether women should become "stay at home" mothers or "working mothers," encapsulated in the term "Mommy Wars” (Douglas, 2000; Douglas and Michaels, 2005; Warner, 2006). The assumption within this debate, holds that working mothers are "prevented by employment from being full-time mothers" (Ranson, 2004, p. 89), and that mothers should practice what Sharon Hays (1996) calls "intensive mothering. Intensive mothering prescribes that a mother is the primary (even sole) caregiver in the home, devoting herself to her children and nothing else (Arendell, 2000; Hays, 1996; Lorber, 1995; Macdonald, 1998; O’Reilly, 1996; Schlessinger, 2000). Thus, a "good" mother cannot divide her attention, energy or time between paid work and her children (Johnston \& Swanson, 2004; Ranson, 2004). It is within this framework that intensive mothering is portrayed 
as a prescription for action and a value-laden choice that women make: either women are choose to work for pay, or opt out of this work to nurture their young children in their formative early childhood years at home (Christopher, 2012; Elvin-Nowak and Thompson, 2001; Garey, 1999; Hattery, 2001; Johnston and Swanson, 2006, 2007; Sutherland, 2006). Within this discourse, a woman's child -- and her child's success or failures -- become "the results of her maternal instincts, her worth as a human being” (Tardy, 2000:444). Any decision to work for pay outside of the home goes against the prescriptions of intensive motherhood.

Lisa Belkin's (2003) "The Opt-Out Revolution" in The New York Times encapsulated part of this by depicting the "opting-out" of employment by college educated career women as "free choice" to enter into the domain of being "full-time” mother. Many scholars, including Heather Dillaway and I (Pare \& Dillaway, 2005; Dillaway and Pare, 2008) were critical of this assessment, arguing that this image of "opting out" presented a limited and false narrative of choice and masked reality. In reality, most working women do not opt out of paid work for motherhood. Most women continue to combine paid work and motherhood out of economic necessity, and those who do "opt out" are often pushed out by inflexible workplace policies and cultures (Stone, 2007; Williams \& Dolkas, 2012); therefore, opting out is not necessarily a choice that women make out of free will, after having considered two or more equal options. Women's “decisions" to exercise agency as they negotiate decisions around paid work and motherhood are not based on free choice alone, then, but are instead made within existing structural, material, and time constraints (Paré, 2015; Stone, 2007; Williams \& Dolkas, 2012). Further, as structural constraints become stricter, so do women's “choices.” For instance, the women once touted by Belkin (2003) as "opting out” often opted back in during recent years, due to economic changes within their families (Warner, 2013). Opting back in, however, meant that the majority of women entered back in lower level positions, with reduced pay and less stability than in their previous positions and their families have felt additional economic strain as a result (Warner, 2013).

New economic pressures often eventually give way to new constructions of paid work and motherhood, expanding or alternative the cultural discourse in the long term. While 5.2 million married mothers with children under 15 years of age are classified as "stay at home" (Census, 2014) and this is still a significant portion of women, the cultural discourse has moved on from the "Opt-Out Revolution" and the "Mommy Wars" to discussions on why, how and when women should "lean in" -- ushered in by Sheryl Sandberg, the COO of Facebook, and her TED talk which later became the basis for her book, Lean In: Women, Work and the Will to Lead (2013). Sandberg argued that women pull back on their high-powered careers long before having children but, instead, they need to "lean in" further into career. This call for women to not only stay in the workplace, but also to push oneself forward into higher level positions, does not eliminate the expectation that mothers will continue to act primary caregivers who are fully invested in their children's well-being (Slaughter, 2012). The cultural expectation is still that a mother will produce "good" children (re: successful children) 
through "good" mothering. Acknowledging this, Sandberg (2013) offers, "Guilt management can be just as important as time management for mothers.” (pg. 137). Popular books such as Lean In suggest a cultural acknowledgment that women are in the paid workforce, and that there is pressure to do both paid work and mothering well.

\section{Competitive Mothering}

In light of the changing economy, and out of necessity, women have had to increasingly manage paid work and motherhood. With younger women having rates of paid work nearly equal to that of men (Alvesson \& Due Billing, 2009), it is not a surprise that the contemporary mothering image is that of a professional working mother who manages to succeed both in the workforce and on the home front as she "leans in" (Sandberg, 2013; Van Meter, 2015). This means that the social discourse has too shifted in that it focuses more on which working mothers are doing a "good" job at mothering, rather than whether working mothers can be good mothers. Within an uncertain and changing global marketplace, children provide the tools by which a mother can demonstrate how her "choice" (of how to work and how to mother, and how to combine the two roles) is indeed the right one. As discussed below, mothers performatively "secure" families as they demonstrate their abilities to manage both motherhood and paid work (Cooper, 2014). With the context of a well-documented and increasing need for both parents to work, it appears these working mothers reframe mothering and paid work to indicate how they are still "in charge" of their children's care even if not home full-time (Christopher, 2012). Mothers who are career professionals, with higher education levels and incomes, are able to outsource aspects of "intensive" mothering in a way provides their children more opportunities to compete in the global marketplace and become "successful” adults (Christopher, 2012; Cooper, 2014).

Additionally, decisions of how to combine intensive mothering and paid work become a form of "doing security" for the family, and this "security work" is disproportionately occupied and performed by women: Women act as the “family's security guards...charged with keeping insecurity at bay while their husbands [are] comparatively less burdened” (Cooper, 2014). Because women's wage work has historically been devalued and women have always been defined as tied to the home (Dillaway and Pare, 2008; Kessler-Harris, 2001), there has been an uninterrupted, longstanding link between demonstrating "good" motherhood and creating economic security for their families (Villalobos, 2014) and, in the process women help families to maintain a middle- or upper-class lifestyle (Cooper, 2013; Cooper, 2015). Lareau (2003) noted middle- and upperclass parenting practices are more time intensive than those of working class parents; this is concerted cultivation. Middle and upper-class parents consciously make possible children's participation in organized extracurricular activities, are active with children in the home, and monitor their activities and promote children's long term success (Lareau, 2003). In light of recent economic changes and downturns, however, there is an intense anxiety among the middle-class in particular when it comes to preserving their class advantage (Cohen, 2015; 
Jefferson, 2015; Walsh, 2015). Motherhood today has an increasingly intensive end point, then; it is not merely giving one's all to one's children, but it involves doing in order to secure successful futures through intensive, extensive, and expanded mothering throughout a child's life (Nelson, 2010). In our 2005 article, we argued that " $A$ redirection of the conceptualization of mothering and work would allow for women to see motherhood not as a competitive sport, but as a practice that needs support across the social and political spectrum” (Paré \& Dillaway, 2005). With the increased need to secure economically secure futures for children, I do not see the competitive nature of intensive motherhood or its security function dissipating any time soon.

\section{Not All Mothers}

On the other hand, not all women are equally qualified or valued for their efforts to provide security. Women in low-wage positions, women whose paid labor is caregiving-based, women who are low-income, and women who do not earn a paid wage are not equally valued, and their decisions and actions surrounding motherhood and work are not praised (Peterson, 2016). Unlike the cultural discourse that suggests that women can advocate for themselves within the existing system and create systemic change through their presence (DallaCamina, 2012; Sandberg, 2013), diverse groups of women are not able to do this simply because of the positions they hold in the workforce. Nearly two-thirds of the nearly 20 million workers (Entmacher et al., 2014) are in low-wage jobs that hold little to no decision-making power (Bernhardt, McKenna, \& Evangelist, 2012), especially since any job growth since the recession is primarily in these types of jobs. Women in low-wage positions are less likely to have autonomy in the work force and experience greater levels of work-conflict than women in more prestige positions (Weigt \& Solomon, 2008). This limits working women’s ability to have an impact on systemic change within the workplace.

Moreover, more than 25 percent of U.S. households with children under age 18 are headed by single parents (Livingston, 2013), which means they have little extra time to prioritize making change in the workplace or interacting with their children in an intensive way (Barnes 2015; Jones 2009). Women in lowwage positions also lack time to focus on guilt management or other "middleclass" concerns (Hennessy, 2015); instead, their focus is on providing for basic needs (maintaining an instrumental security rather than forms of security that middle- or upper-class working women might be able to focus on).

In addition, women in low-wage positions are less likely to be viewed in positive terms when they attempt to provide economically for their children (Povich, Roberts, \& Mather, 2013); thus, their paid labor is not seen as creating economic (or other) security in the first place. Within the context of cultural discourse that assumes concerted cultivation as a form of intensive mothering to properly secure children's futures through their parenting (Lareau, 2003; Cooper, 2015), women in low-wage positions who are unable to uphold this intensive mothering are seen as unable to create real security for their children, presumably leaving their children disadvantaged in the face of the changing economy. Ultimately, disadvantaged women's ability to compete both within the economic 
marketplace and in upholding motherhood prescriptions has continued to decline as class insecurity has grown.

\section{Conclusion: Expanding the Call}

On the surface, the mainstream cultural discourse has shifted away from the "stay at home" mother versus "working” mother since we wrote our 2005 article, but the discourse has not really become more inclusive, or more open to discussing the complex negotiations mothers face in the everyday. As a result, I still agree with our original article's premise that:

Instead of promoting a divisive ideology and contradictory dichotomies, feminist scholars, journalists, and lay parents and workers need to focus on the connections across mothering, fathering, and working experiences, and the common negotiations adults face as they engage in parenting and paid work (Paré \& Dillaway, 2005).

With the continued and competing expectations of paid work and motherhood, and the declining of families' economic positions within the new global marketplace, the ability to adhere to intensive mothering has become increasing difficult, resulting in the recent discussions on the negative effects of modern mothering choices for women (e.g., Alcorn, 2013; Senior, 2014; Schulte, 2015). With men experiencing changes in the cultural expectations of fatherhood as well (Milkie \& Denny, 2014), there is potential for an increase in men's work-family conflict (Aumann, Galinksy, \& Matos 2011; Ranson, 2012; Bianchi, Robinson, \& Milkie 2006; Doucet, 2006; Doucet, 2016). More research is needed on how the changes in the economy and increasing decline of the middle class have impacted how mothers and fathers conceptualize their parenting roles, and also how parenting identities may continue to change across class, race and familial structures. All parents struggle with the need both to be more involved with their children and secure their futures, while also maintaining the involvement in paid work settings and securing their own positions within the labor force over time. Securing families and securing paid work go hand in hand, and much more research needs to be done to understand actual work-family decisions and actions after the most recent downturns and recessions in the U.S. Additional research is also needed to understand the ways in which intensive mothering ideology has shifted, expanded, and become more extensive as children's middle-class futures become more economically precarious.

\section{References}

Alcorn, K. (2013). Maxed out: American moms on the brink. Berkeley, CA: Seal Press.

Alvesson, M., \& Billing, Y. D. (2009). Understanding gender and organizations $\left(2^{\text {nd }}\right.$ ed). Thousand Oaks, CA: Sage.

Arendell, T. (2000). Conceiving and investigating motherhood: The decade's scholarship. Journal of Marriage and Family, 62(4), 1192-1207.

DOI: 10.1111/j.1741-3737.2000.01192.x 
Aumann, K., Galinsky, E. \& Matos, K. (2011). The new male mystique. New York: Families and Work Institute.

Baca Zinn, M., \& Eitzen, S. D. (2005). Diversity in families (8th ed.). Boston, MA: Allyn \& Bacon.

Barnes, R. J. D. (2015). Raising the race: Black career women redefine marriage, motherhood, and community. New Brunswick, NJ: Rutgers University Press

Belkin, L. (2003). The opt-out revolution. New York Times Magazine (October 26).

Bernhardt, A., McKenna, C., \& Evangelist, M. (2012). The low-wage recovery and growing inequality. National Employment Law Project Data Brief. New York, NY: National Employment Law Project. Retrieved from http://nelp.org/content/uploads/2015/03/LowWageRecovery2012.pdf

Bianchi, S. M., Robinson, J.P, \& Milkie, M.A. (2006). Changing rhythms of American family life. New York: Russell Sage Foundation.

Bonikowski, B., \& DiMaggio, P. (2016). Varieties of American popular nationalism. American Sociological Review, 81(5), 949-980. DOI: 10.1177/0003122416663683

Christopher, K. (2012). Extensive mothering: Employed mothers’ constructions of the good mother. Gender \& Society, 26(1), 73-96. DOI: $10.1177 / 0891243211427700$

Cline, W. R., \& Nolan, J. (2014). Demographic versus cyclical influences on US labor force participation. Peterson Institute for International Economics Working Paper (14-4).

Cohen, P. (2015). Middle class, but feeling economically insecure. The New York Times, B1.

Cooper, L. (2013). Women and higher education: Narratives of middle-class, mother-daughter dyads. Gender and Education, 25(5), 624-639. DOI: 10.1080/09540253.2013.810711

Cooper, L. (2015). The maternal gift: mothers' investment in their daughters' higher education. Journal of Further and Higher Education, 1-12. DOI: 10.1080/0309877X.2015.1100716

Cooper, M. (2014). Cut adrift: families in insecure times. Berkeley, CA: University of California Press.

Craig, Lyn. 2006. Does father care mean fathers share? A comparison of how mothers and fathers in intact families spend time with children. Gender \& Society, 20, 259-81. DOI: 10.1177/0891243205285212

Dalla-Camina, M. (2012). Getting real about having it all. Australia: Hay House.

DeNavas-Walt, C., Proctor, B. D., \& Smith, J. C. (2012). Income, poverty, and health insurance coverage in the United States. US Census Bureau.

Dill, B. T., Baca Zinn, M., \& Patton, S. (1998). Valuing families differently: Race, poverty and welfare reform. Sage Race Relations Abstracts, 23(3), 4-30.

Dillaway, H., \& Paré, E. (2008). Locating mothers how cultural debates about stay-at-home versus working mothers define women and home. Journal of Family Issues, 29(4), 437-464. DOI: 10.1177/0192513X07310309 
Doucet, A. (2006). Do men mother? Fathering, care and domestic responsibility. Toronto: University of Toronto Press

Doucet, A. (2016). Single fathers. The Wiley Blackwell encyclopedia of family studies. DOI: 10.1002/9781119085621.wbefs396

Douglas, S. (2000). The Mommy Wars: How the media turned motherhood into a catfight. Ms. Magazine (February/March).

Ellen, I., \& Dastrup, S. (2012). Housing and the Great Recession. New York and Palo Alto: The Russell Sage Foundation and the Stanford Center on Poverty and Inequality.

Elvin-Nowak, Y., \& Thomsson, H. (2001). Motherhood as idea and practice a discursive understanding of employed mothers in Sweden. Gender \& Society, 15(3), 407-428. DOI: 10.1177/089124301015003005

Entmacher, J., Frohlich, L., Robbins, K. G., Martin, E., \& Watson, L. (2014). Underpaid and overloaded: Women in low-wage jobs. Washington, DC: National Women's Law Center.

Garey, A. (1999). Weaving work \& motherhood. Philadelphia: Temple University Press.

Goldstein, J. L., \& Peters, M. E. (2014). Nativism or economic threat: Attitudes toward immigrants during the Great Recession. International Interactions, 40(3), 376-401. DOI: 10.1080/03050629.2014.899219

Greenstone, M. \& Looney, A, (2010, August 6). The long road back to full employment: How the Great Recession compares to previous U.S. recessions. The Brookings Institution. Retrieved from http://www.brookings.edu/opinions/2010/0806_employment_looney_gree nstone.aspx

Hattery, A. (2001). Tag-team parenting: Costs and benefits of utilizing nonoverlapping shift work in families with young children. Families in Society: The Journal of Contemporary Social Services, 82(4), 419-427. DOI: 10.1606/1044-3894.185

Hennessy, J. (2015). Work and family commitments of low-income and impoverished women: Guilt is for mothers with good jobs. Lanham, MD: Lexington Books.

Hondagneu-Sotelo, P., \& Avila, E. (1997). "I'm here, but I'm there": The meanings of Latina transnational motherhood. Gender \& Society, 11(5), 548-571. DOI: 10.1177/089124397011005003

Hyra, D. S., Squires, G. D., Renner, R. N., \& Kirk, D. S. (2013). Metropolitan segregation and the subprime lending crisis. Housing Policy Debate, 23(1), 177-198. DOI: 10.1080/10511482.2012.697912

Inglehart, R., \& Norris, P. (2016). Trump, Brexit, and the rise of Populism: Economic have-nots and cultural backlash. HKS Working Paper No. RWP16-026.

Jefferson, A. (2015). "Not what it used to be”: Schemas of class and contradiction in the Great Recession. Economic Anthropology, 2, 310-325. DOI: 10.1002/sea2.12033 
Johnston, D., \& Swanson, D. (2004). Moms hating moms: The internalization of mother war rhetoric. Sex Roles, 51, 497-510. DOI: 10.1007/s11199-0045460-X

Jones, B. D. (2012). Women who opt out: The debate over working mothers and work-family balance. New York: New York University Press.

Jones, J. (2009). Labor of love, labor of sorrow: Black women, work, and the family, from slavery to the present. New York: Basic Books.

Kessler-Harris, A. (1983). Out to work: A history of wage-earning women in the United States. New York: Oxford University Press.

Kessler-Harris, A. (2001). In pursuit of equity: Women, men, and the quest for economic citizenship in 20th-century America. New York: Oxford University Press.

Kirk, D. S., \& Hyra, D. S. (2012). Home foreclosures and community crime: Causal or spurious association? Social Science Quarterly, 93(3), 648-670. DOI: 10.1111/j.1540-6237.2012.00891.x

Kochhar, R., Fry, R., \& Rohal, M. (2015). The American middle class is losing ground. Pew Research Center Report.

Lareau, A. (2003). Unequal childhoods: Class, race, and family life. Berkeley, CA: University of California Press.

Lorber, J. (1995). Rocking the cradle: Gendered parenting. In J. Lorber (Ed.), Paradoxes of gender (pp. 144-171). New Haven, CT: Yale University Press.

Macdonald, C. L. (1998). Manufacturing motherhood: The shadow work of nannies and au pairs. Qualitative Sociology, 21(1), 25-48. DOI: 10.1023/A:1022119309086

Mann, S. A., Grimes, M. D., \& Kemp, A. A. (1997). Paradigm shifts in family sociology? Evidence from three decades of family textbooks. Journal of Family Issues, 18, 315-349. DOI: 10.1177/019251397018003005

Milkie, M. A., \& Denny, K. E. (2014). Changes in the cultural model of father involvement: Descriptions of benefits to fathers, children, and mothers in Parents’ Magazine, 1926-2006. Journal of Family Issues, 35(2), 223-253. DOI: $10.1177 / 0192513 X 12462566$

Nelson, M. (2010). Parenting out of control: Anxious parents in uncertain times. New York: New York University Press.

Newman, K. S. (1994). Troubled times: The cultural dimensions of economic decline. In M. A Bernstein \& D. Adler (Eds.), Understanding American economic decline. New York: Cambridge University Press.

O'Reilly, A. (1996). Ain't that love? Antiracism and racial constructions of motherhood. In M. T. Reddy (Ed.), Everyday acts against racism. Seattle, WA: Seal Press.

Paré, E. R. (2015). “It’s a choice”: Graduate student mothers' sense of agency in decision-making. Journal of the Motherhood Initiative for Research and Community Involvement, 6(2), 52-64.

Paré, E. R., \& Dillaway, H. E. (2005). "Staying at home” versus “working”: A call for broader conceptualizations of parenthood and paid work. Michigan Family Review, 10(1), 66-85. 
Peterson, J. (2016). The well-being of working women in times of economic crisis and recovery: Insights from the Great Recession. In Handbook on wellbeing of working women (pp. 517-539). Springer Netherlands.

Povich, D., Roberts, B., \& Mather, M. (2013). Low-income working mothers and state policy: Investing for a better economic future. Policy Brief: The Working Poor Families Project Report. Retrieved from https://www.chapa.org/housing-policy/research-reports/working-poorfamilies-project-policy-brief-low-income-working.

Ranson, G. (2004). Paid work, family work and the discourse of the full-time mother. In A. O’Reilly (Ed.), Mother matters: Motherhood as discourse and practice (pp. 87-97). Toronto, Canada: Association for Research on Mothering.

Ranson, G. (2012). Men, paid employment and family responsibilities: Conceptualizing the 'working father'. Gender, Work \& Organization, 19(6), 741-761. DOI: 10.1111/j.1468-0432.2011.00549.x

Rose, S. \& Winship, S. (2009). Ups and downs: Does the American economy still promote upward mobility? Report from the Pew Charitable Trust's Economic Mobility Project. Retrieved from www.economicmobility.org.

Rubin, L. (1994). Families on the fault line: America's working class speaks about the family, the economy, race, and ethnicity. New York: HarperCollins.

Sandberg, S. (2013). Lean in: Women, work, and the will to lead. New York: Random House.

Schlessinger, L. (2000). Parenthood by proxy: Don't have them if you won't raise them. HarperAudio/HarperCollins ebooks.

Schulte, B. (2015). Overwhelmed: How to work, love, and play when no one has the time. New York: Macmillan.

Senior, J. (2014). All joy and no fun: The paradox of modern parenthood. New York: HarperCollins Publishers.

Slaughter, A. M. (2012). Why women still can't have it all. The Atlantic Monthly, July/August. Retrieved from https://www.theatlantic.com/magazine/archive/2012/07/why-women-stillcant-have-it-all/309020/

Smith, D. (1993). The standard North American family: SNAF as an ideological code. Journal of Family Issues, 14(1), 50-65. DOI:

10.1177/0192513X93014001005

Stone, P. (2007). Opting out?: Why women really quit careers and head home. Berkeley, CA: University of California Press.

Sutherland, J. (2006). Guilt and shame: Good mothering and labor force participation. Presentation. American Sociological Association Annual Meeting, Montreal, Quebec, Canada. August.

Tardy, R. (2000). 'But I am a good mom': The social construction of motherhood through health-care conversations. Journal of Contemporary Ethnography, 28, 433-73. DOI: 10.1177/089124100129023963

Uttal, L. (2002). Making care work: Employed mothers in the new childcare market. New Brunswick, NJ: Rutgers University Press. 
Van Metter, J. (2015). Ivanka Trump knows what it means to be a modern millennial. Vogue, March.

Villalobos, A. (2014). Motherload: Making it all better in insecure times. Berkeley, CA: University of California Press.

Walls, J. K., Helms, H. M., \& Grzywacz, J. G. (2014). Intensive mothering beliefs among full-time employed mothers of infants. Journal of Family Issues, 37 (2), 245-269. DOI: 10.1177/0192513X13519254.

Walsh, J. (2015). Goodbye, middle class, hello, Donald Trump. The Nation, December 14.

Warner, J. (2013). The opt-out generation wants back in. The New York Times, August 7.

Warner, J. (2005). The mommy madness generation. Newsweek (February), 4249.

Wachter, S. M., \& Smith, M. M. (Eds.). (2011). The American mortgage system: Crisis and reform. Philadelphia: University of Pennsylvania Press.

Weigt, J. M., \& Solomon, C.R. (2008). Work-family management among lowwage service workers and assistant professors in the USA: A comparative intersectional analysis. Gender, Work \& Organization, 15(6): 621-49. DOI: 10.1111/j.1468-0432.2008.00419.x

Williams, J. C., \& Dolkas, J. (2012). The opt-out revolution revisited. In B. D. Jones (Ed.), Women who opt out: The debate over working mothers and work-family balance (pp. 151-176). New York: New York University Press. 